\title{
New Concerns in International Business: The Application of Sanitary and Phytosanitary Policies
}

\author{
Maria Esther Kim \\ University of Buenos Aires, Buenos Aires, Argentina,kim.mariaa@gmail.com
}

\begin{abstract}
In recent years, the debate over the application of non-tariff measures for environmental protection as a new form of disguised restriction on international trade by developed countries has become increasingly important. While tariffs have decreased over the decades, the increasing application of environmental-related requirements are a new factor that affects international business. These new requirements not only modify companies' decision-making processes at national and international levels, but also within the firm. Hence, this paper proposes to examine the application of such measures by the European Union in the tea, coffee and yerba mate market, and their impact on exporting Latin-American firms for the 1995-2015 period and analyze whether there has been an improvement in their productive quality. For this aim, through a qualitative methodology, we carried out interviews with specialists of the field and surveys to Latin-American exporting companies. In this way, this analysis discusses with theorists if the application of measures related to environmental sustainability leads to ameliorate firms' productive quality. Among the results, it is highlighted the fact that non-tariff measures - in particular sanitary and phytosanitary ones - have been used as trade barriers. However, complying with them allows exporting companies to develop environmental performance strategies and ultimately, it leads to a positive growth in their productive quality in the medium-long term.
\end{abstract}

KEYWORDS: non-tariff measures, trade barriers, sanitary and phytosanitary policies, productive quality

\section{Introduction}

In the last decades, the exponential increase of deregulation of national industries and foreign investment, new trade agreements and regional cooperation in trade issues are clear evidences of the advance of globalization. In this context, tariffs have decreased - especially after the Uruguay Round, when member countries committed to reduce them. However, paradoxically, Non-Tariff Measures (NTMs) started to become increasingly important, and by the 1990s, their impact in international business and trade was inevitable.

At the same time, concerns about the environment and sustainability have gained a primordial place in the international agenda. Thus, different countries are increasingly applying sanitary and phytosanitary measures (SPS) with the aim to protect, prevent and preserve human, animal and plant health. The application of such standards - mainly applied by developed countries - led to affected exporting developing countries to be strongly concerned about their businesses, as they do not only restrain their market access, but also, they imply huge costs, as if firms cannot comply with them, they can be in disadvantage, losing competitiveness.

In consequence, exporters of the affected primary goods have shown strong criticism, claiming that these standards serve as hidden restrictions on trade. Although many experts have provided evidence of the negative effects of these measures in the short term, it may be possible for companies to overcome the assumed costs in the long term, and eventually improve their competitiveness through innovation. According to Galperin (2013), standards only have negative effects on exporters when they are not able to comply with them, as it is possible to observe an increase in exports sales in those companies that do.

Therefore, it is necessary to work in the development of strategies so that both trade and environmental goals are achieved, in a way that neither of them is harmed. As it is observed, the challenge lies in the improvement of productive systems, which requires regional and international cooperation (Kim 2018).

Thus, in this paper, our main goal is to discuss how the application of SPS affect international business. In order to do so, we study the effects of their application by the EU in the coffee, tea and 
mate market in Latin-America. By surveying companies involved in the infusion industry, we measure the results in a period of 10 years.

From the results, it is expected to find that although these measures may have negative impacts in the short term, it is possible for firms to overcome these costs in the long term. In fact, those companies that have complied with NTMs may establish more environmental goals and give more importance to sustainable development than the ones that have not. Hence, if firms comply with SPS, they may improve their competitiveness.

\section{Coffee, tea and mate industry in Latin America}

The three drinks to be analyzed in this paper play an important role in the regional agricultural industry. In the case of coffee, South America, Central America and Mexico have represented more than $60 \%$ of the total global production from 2013 to 2017 (IHCAFE 2017). In fact, by 2013, 7 out of the 20 top coffee exporters were Latin-American: Brazil (who is in fact the first coffee exporter in the world), Colombia, Honduras, Peru, Guatemala, Mexico and Nicaragua (ICO 2013). Additionally, because regional consumption of coffee is relatively low (around $2.5 \mathrm{kilos} /$ person per year) compared to the global average ( $4.5 \mathrm{kilos} /$ person per year), the region has exported $90 \%$ of its production between 1980 and 2011 (Brenes and Viquez 2016).

Production and export of tea and yerba mate are not as widely known internationally as coffee, but they are still an interesting market to be analyzed for two main reasons: the first one is that their consumption are expected to increase potentially in the following years; the second one is that the EU apply many non-tariff measures that affect these markets and seem to present a threat to Latin-American exports' growth in the short-term.

In the case of yerba mate, this drink is becoming a trend in international markets. The consumption of this beverage has been increasing throughout the decades, which can represent a window of opportunity for Argentina, Brazil and Paraguay. Currently, the market is concentrated in these three South American countries. While Argentina remained the leader in exports in FOB terms by 2013, Brazil did so in terms of exported tons. Paraguay is self-sufficient and it also generates exportable balances, while the Uruguay market is supplied by the Brazilian market through linked businesses.

In the case of the tea market, Latin-American countries represent a very small proportion of the global tea production. Among the most important producing countries are Brazil and Argentina. According to the analyzed information from FAO, Argentina is among the top 10 tea exporters in the world, representing around $2 \%$ of the global production of tea in 1995, 2010 and 2015, and $1.5 \%$ of the total exports. Being among the top 10 exporters in the world, Argentine's tea industry has shown a growth tendency since the beginning of 2000s. It is important to highlight that among the most important importers of Argentine tea we find members of the European Union.

\section{Methodology}

In order to analyze the impact of NTMs in Latin America, we surveyed 39 different Latin-American companies that are involved in the coffee, mate and tea industries. The survey was made in 2018 with the purpose to study these firms' decision-making processes and actions in the last 10 years in terms of cost perception, NTMs compliance, and sustainability strategies (Kim 2018).

Experts on the area were contacted via email and social media such as LinkedIn and Facebook. Among the respondents of the survey we find production, logistics, and exports managers, quality experts, company owners and safety assistants. The survey consisted of 34 questions, which were divided in three sections: the first one was "General Questions", compounded by 11 questions related to the firms' characteristics. The second one was "Non-Tariff Measures", which had 17 questions related to the companies' perception of NTMs and their compliance. The third section was "Sustainable Development", which consisted of 6 questions related to the companies' strategies and decisions on this matter. 
For this study, we analyze whether there is a correlation between compliance with NTMs and positive effects in the long-term plus an orientation towards sustainability and a more positive view over the application of these measures. For that aim, it was necessary to add questions that served as direct indicators. Hence, for the firms' compliance with NTMs, we asked the companies about their level of compliance in four different types of measures: maximum levels of contaminants, packaging and technical certifications. Answers were divided in 5 main categories: "Excellent Compliance", "Moderate Compliance", "Low Compliance" and "Null Compliance". Then, we added questions where companies had to show their opinion regarding the application of such measures, and the evolution of the productive capacity and exports in a period of 10 years. Mainly, we asked them about the introduction of sustainable technology, the evolution of the use of water, if they established environmental performance goals for the firm, and how their productive capacity and competitiveness improved in the last 10 years. Combined, these indicators will allow us to study the correlation between the variables.

Before measuring the results, it is important to mention some general results of the survey. In general terms, 10 different countries participated of the survey. As we observe in Figure 1, 23\% of the surveyed firms were from Mexico, followed by Argentina (18\%) and then Peru (15\%). Additionally, it is important to highlight that $72 \%$ of the total surveyed firms claimed to be specialized in coffee, $21 \%$ in yerba mate, and only $8 \%$ in tea, which is explained by the fact that tea is mostly produced in Argentina and Brazil, and also, its production is concentrated in few companies.

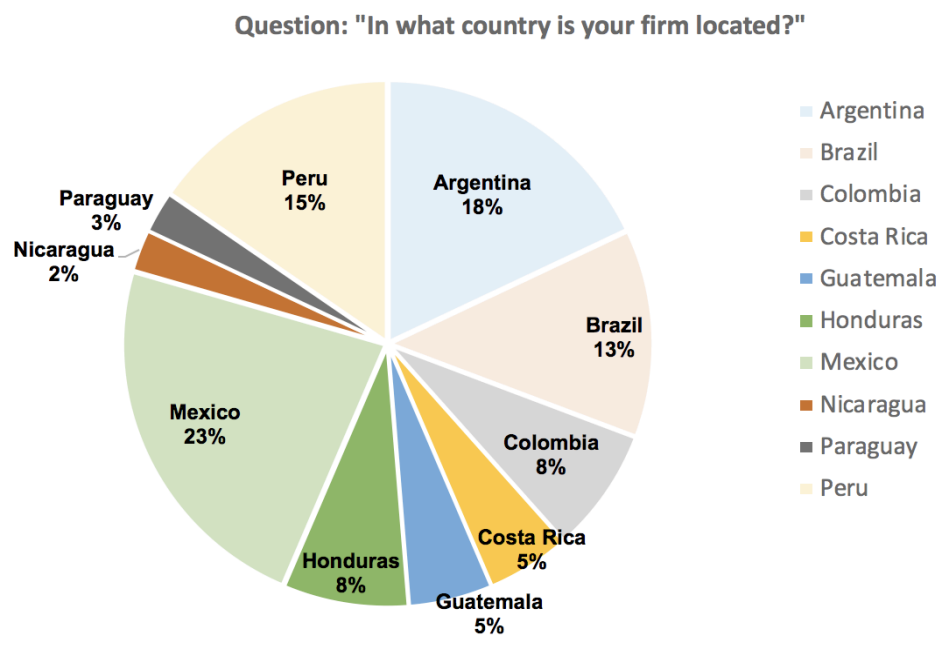

Figure 1. Question of survey: "In what country is your firm located?"

Lastly, it is important to highlight the strong relationship that Latin-American firms have with European Union. They were asked to give a number from 1 (most important) to 8 (least important) depending on the importance that they give to each of the following regions in terms of exports: North America, Central America, South America, European Union, Rest of Europe, Africa Asia and Oceania. From our results, we observe that $62 \%$ of the surveyed companies said that the EU was among their exports' main destinations (from 1 to 4 ).

\section{Results}

Among the first results, it is important to mention that most companies have shown to have a good compliance with NTMs. When asked about the Maximum Levels of Contaminants/Residues, around $56 \%$ informed that they have had an "excellent compliance", followed by a $38 \%$ of "moderate compliance". A very similar result was obtained when firms were asked about the packaging requirements (see Table 1). Then, almost $70 \%$ of the firms selected the category "excellent compliance" when asked about technical certifications required by importing countries. As we observe, although it may be costly for firms to comply with these requirements, evidence shows that most of them do. 
Table 1. Results obtained to questions related to the firms' level of compliance with NTMs

\begin{tabular}{|c|c|c|c|c|c|c|}
\hline Compliance Level & $\begin{array}{l}\text { What was your firm's level of } \\
\text { compliance of the Maximum Levels of } \\
\text { Contaminants/Residues requirements } \\
\text { on your products? }\end{array}$ & $\%$ & $\begin{array}{l}\text { What was your firm's level of } \\
\text { compliance in order to obtain technical } \\
\text { certifications required by importing } \\
\text { countries on your products? }\end{array}$ & $\%$ & $\begin{array}{l}\text { What was your firm's level of } \\
\text { compliance of the packaging } \\
\text { requirements on your products? }\end{array}$ & $\%$ \\
\hline $\begin{array}{c}\text { Excellent } \\
\text { Compliance }\end{array}$ & 22 & $56 \%$ & 27 & $69 \%$ & 22 & $56 \%$ \\
\hline $\begin{array}{c}\text { Moderate } \\
\text { Compliance }\end{array}$ & 15 & $38 \%$ & 9 & $23 \%$ & 14 & $36 \%$ \\
\hline Low Compliance & 1 & $3 \%$ & 1 & $3 \%$ & 1 & $3 \%$ \\
\hline Null Compliance & 1 & $3 \%$ & 2 & $5 \%$ & 2 & $5 \%$ \\
\hline TOTAL & 39 & $100 \%$ & 39 & $100 \%$ & 39 & $100 \%$ \\
\hline
\end{tabular}

In order to analyze the correlation between degrees of compliance and results in the long term, we compare the results of Figure 2 with some indicators that help us to understand firms' growth in the last ten years. First, we asked firms about the evolution of their exports in the last ten years. The categories were divided in 5, from which more than $50 \%$ of the surveyed firms selected "increased" (Figure 2). Categories "increased" and "increased significantly" sum $66 \%$ of the total answers. An even more positive result was observed when we asked firms about the evolution of the firm's productive capacity in that period, as these two categories summed almost $80 \%$ of the total. The main difference was that there were more firms that said they have increased their production capacity (around 26\%).

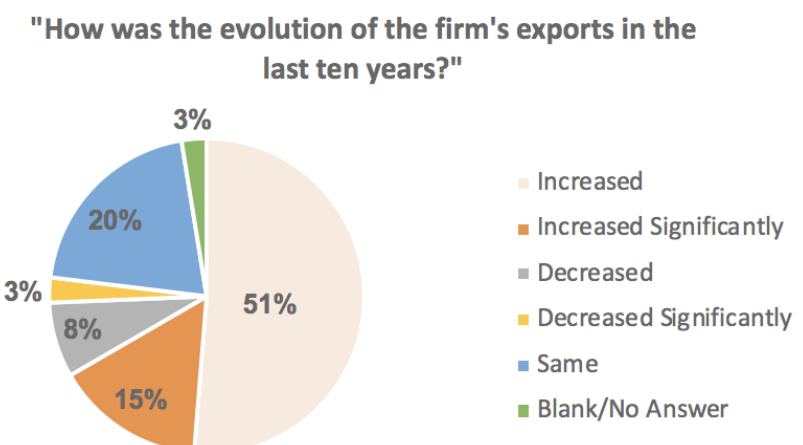

Figure 2. Results obtained to the question: "How was the evolution of the firm's exports in the last ten years?"

When we combine the answers of the surveyed firms of questions under Figures 2 and Table 1, we obtained that most companies that had complied excellently with packaging requirements also informed that their exports "increased" (45\%) or "increased significantly" $(23 \%)$ in the last ten years. Only three firms have declared to have null compliance or low compliance, but all of them did not have an increase of their exports in that same period (Table 2). The other two questions related to compliance show similar results, which lead us to confirm a correlation between level of compliance and evolution of exports in the long-term.

Table 2. Correlation between level of compliance with packaging requirements and evolution of exports in the last ten years

\begin{tabular}{|c|c|c|c|c|c|c|c|}
\hline \multirow{2}{*}{$\begin{array}{l}\text { What was your firm's level of } \\
\text { compliance of the packaging } \\
\text { requirements on your products? }\end{array}$} & \multicolumn{7}{|c|}{ How was the evolution of the firm's exports in the last ten years? } \\
\hline & $\begin{array}{l}\text { Increased } \\
\text { Significantly }\end{array}$ & Increased & Same & Decreased & $\begin{array}{l}\text { Decreased } \\
\text { Significantly }\end{array}$ & $\begin{array}{c}\text { Blank/No } \\
\text { Answer }\end{array}$ & Total Answers \\
\hline Excellent Compliance & $22.73 \%$ & $45.45 \%$ & $13.64 \%$ & $9.09 \%$ & $4.55 \%$ & $4.55 \%$ & 22 \\
\hline Moderate Compliance & $7.14 \%$ & $71.43 \%$ & $21.43 \%$ & $0.00 \%$ & $0.00 \%$ & $0.00 \%$ & 14 \\
\hline Null Compliance & $0.00 \%$ & $0.00 \%$ & $100.00 \%$ & $0.00 \%$ & $0.00 \%$ & $0.00 \%$ & 2 \\
\hline Low Compliance & $0.00 \%$ & $0.00 \%$ & $0.00 \%$ & $100.00 \%$ & $0.00 \%$ & $0.00 \%$ & 1 \\
\hline TOTAL & $15.38 \%$ & $51.28 \%$ & $20.51 \%$ & $7.69 \%$ & $2.56 \%$ & $2.56 \%$ & 39 \\
\hline
\end{tabular}


Similarly, those companies that tend to comply with these measures also have an increase of their production capacity in the last ten years. In order to achieve this result, we compared the answers related to the firms' degree of compliance with technical certifications required by importing countries, and the evolution of their production capacity in the last ten years. We presume that those companies that decided to certify their products had to introduce more sustainable practices and essentially, improve the inefficiencies of their production processes, which would help them improve and increase their productive capacity in the long-term. As we can observe (Figure 3), those companies that selected the category "excellent compliance" tended to increase their production capacity (more than $81 \%$ selected either category "increased" or "increased significantly"). Regarding those companies that showed a moderate compliance, the answers are also positive, but they are slightly lower than the first group. For the total of 3 companies that did not comply at all or had a low degree of compliance, all answers are different, for which it is not possible to make a generalized conclusion.

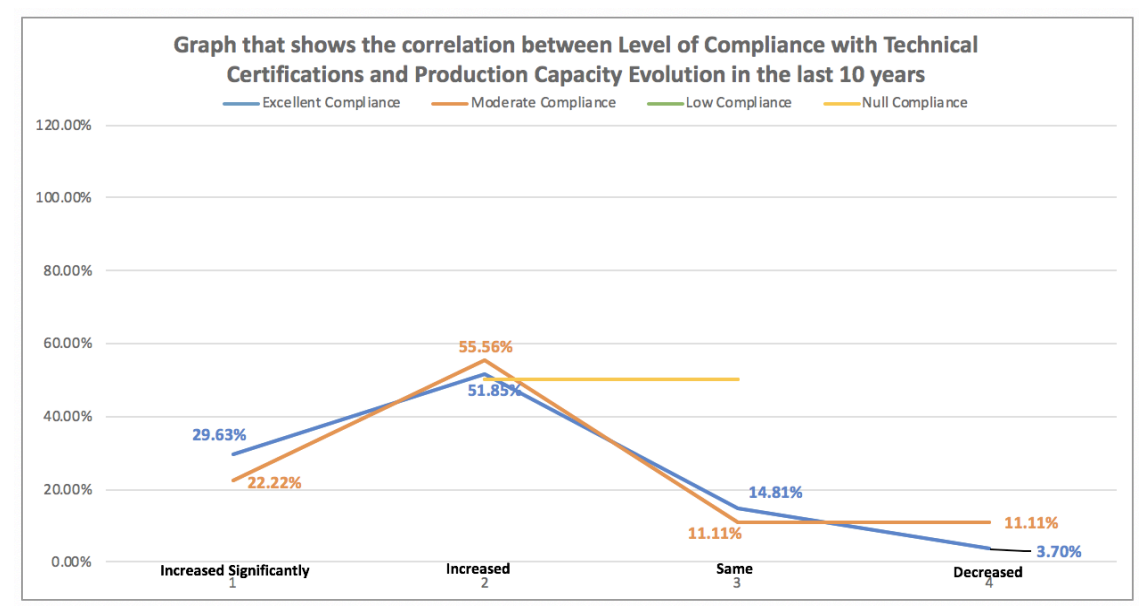

Figure 3. Correlation between Level of Compliance with Technical Certifications and Evolution of Productive Capacity

Thus, we can conclude that regardless of how costly complying with non-tariff measures are, we observe that those companies in the infusions industry in Latin America who comply with non-tariff measures tend to see positive results for their firms in the long term, both in their exports and in their productive capacity. In order to study how firms perceive the impact of NTMs, we asked them to what extent they considered that these measures impact the evolution of their exports. Given the importance of this issue in the international agenda, our first presumption was that most of them would choose the category "it is the main factor that explains the evolution of our exports". However, surprisingly, only 2 firms selected it (5\%). Most of the answers were concentrated in the following two categories (Figure 4), which lead us to conclude that although NTMs are not the main factor, they still have a relevant weight when explaining the evolution of a company's exports.

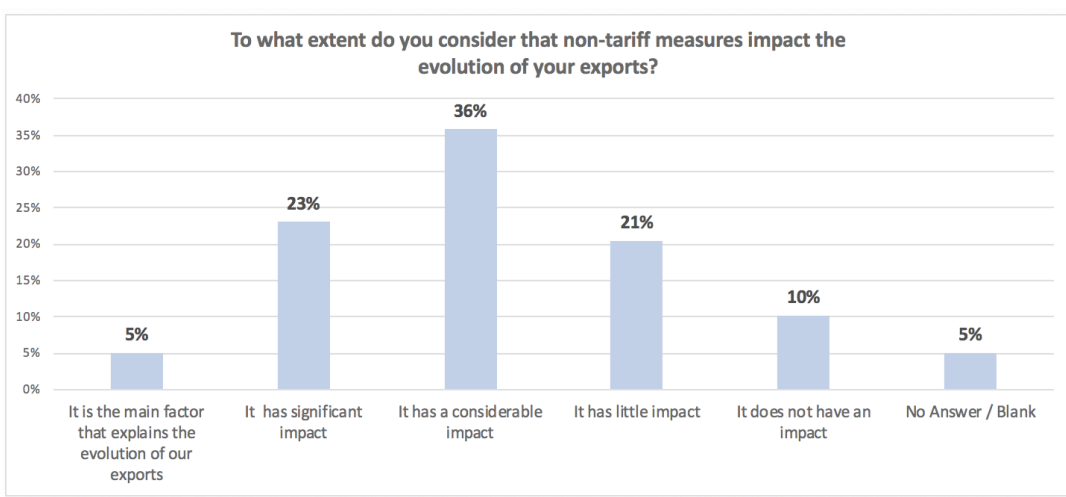

Figure 4. Results obtained to the question "To what extent do you consider that non-tariff measurs impact the evolution of your exports?" 
Moreover, it is possible to observe that there is a general tendency of firms to consider that the NTMs applied by the European Union in this industry can benefit the firm in the long term (around 50\%). However, this perception diverges depending on their level of compliance (Table 3 ). In order to analyze this, all the answers to the questions shown in Figure 2 were combined, and we matched them with the firms' answers to the question: "Do you consider that the NTMs applied by the European Union can benefit your firm in the long term?". Hence, in this case we will not have 39 answers, but instead, 117 (for the three indicators of Level of Compliance). Thus, of all answers of the category "excellent compliance", around 58\% matched the answer of the firm that NTMs could benefit them in the long term. On the contrary, those answers under the categories "low compliance" or "null compliance" tended to match answers that doubted about the benefits of these measures in the long term, and some of them believe that they do not bring such benefits.

Similarly, $64 \%$ of the firms that stated that they comply excellently with the Maximum Levels of Contaminants/Residues requirements agreed that the established maximum levels are the ones that are necessary to preserve human health and should be applied to all firms, against $23 \%$ that decided not to give their opinion, 9\% that selected the category "The maximum levels are correct but could be more flexible", 4\% that stated that "Importers should not establish maximum levels", and none of them opined that "the maximum levels are exaggerated and they should be higher". Differently, firms who had a moderate compliance showed more diverse opinions.

Hence, companies that tend to comply more with Non-Tariff Measures have a more positive perception about their application.

Table 3. Comparison of Levels of Compliance with Certifications, Packaging Requirements and MLRs with the Perception of firms on the benefits that they can provide them in the long term

\begin{tabular}{|c|c|c|c|c|}
\hline \multirow{2}{*}{$\begin{array}{c}\text { Level of Compliance with Certifications, } \\
\text { Packaging and Maximum Levels of } \\
\text { Residues/Contaminants }\end{array}$} & \multicolumn{4}{|c|}{ ¿Do you consider that the NTMs applied by the European Union can benefit your firm in the long term? } \\
\cline { 2 - 5 } & No & Yes & Maybe & Total Answers \\
\hline Excellent Compliance & $8.45 \%$ & $57.75 \%$ & $33.80 \%$ & 71 \\
\hline Moderate Compliance & $13.16 \%$ & $42.11 \%$ & $44.74 \%$ & 38 \\
\hline Low Compliance & $0.00 \%$ & $0.00 \%$ & $100.00 \%$ & 3 \\
\hline Null Compliance & $20.00 \%$ & $0.00 \%$ & $80.00 \%$ & 5 \\
\hline Total Answers & 12 & 57 & 48 & 117 \\
\hline
\end{tabular}

Finally, it is possible to analyze if there is a positive correlation between compliance and commitment with the environmental performance and sustainability development. We presume that firms that have a tendency to comply are also more compromised with a sustainable development.

For that purpose, we first asked firms to provide numbers from 1 to 5 to the importance that their firm gives to the introduction of more sustainable technologies -being 1 "totally unimportant" and 5 "totally important". Among the results, it was found that $82 \%$ of the answers were concentrated in Categories 4 and 5 (Figure 5), with a gap of 30\% or more with the other categories. This shows a general tendency of firms to acknowledge the importance of introducing more sustainable technologies in the firms. Because the results were highly positive, it seems unlikely that there would be real differences in the answers depending on whether firms complied more or less with NTMs. 


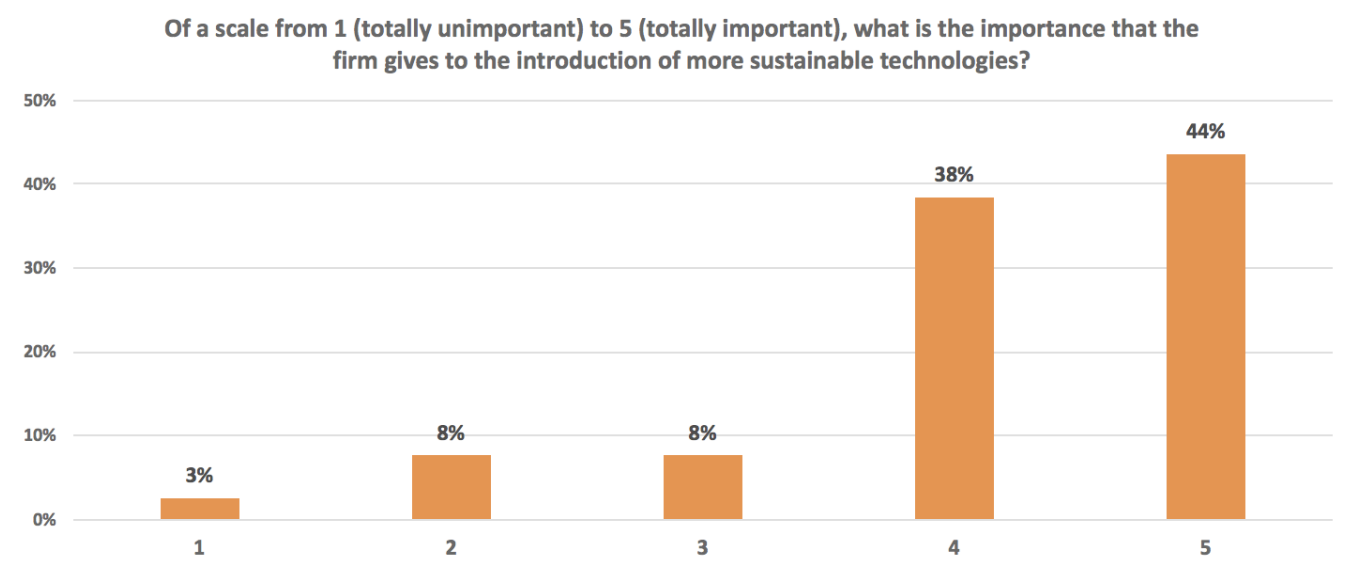

Figure 5. Question "Of a scale from 1 (totally unimportant) to 5 (totally important), what is the importance that the firm gives to the introduction of more sustainable technologies?"

Hence, we compared the degree of compliance in terms of Maximum Levels of Contaminants with the importance given to sustainable technologies. Of those firms that showed an "excellent compliance", around $55 \%$ considered them as totally important, against $41 \%$ that chose category 4 "important", and only $4 \%$ said they were irrelevant (Table 4 ). When we observe the answers of the group of firms "moderate compliance", although the percentage that consider the introduction of more sustainable technologies as important is higher, the answers are more equally distributed among the 5 categories. Regarding the firms in the category "low compliance" and "null compliance", neither of them chose the category 5. Similar results were obtained when comparing the level of compliance in terms of required certifications. However, as in both cases there was only one firm on each category, they might be outliers, so it would not be possible to generalize the results.

Table 4. Correlation between the degree of compliance in terms of Maximum Levels of Contaminants/Residues and Importance given to the introduction of more sustainable technologies

\begin{tabular}{|c|c|c|c|c|c|c|}
\hline \multirow{2}{*}{$\begin{array}{c}\text { What was your firm's level of } \\
\text { compliance of the Maximum Levels } \\
\text { of Contaminants/Residues } \\
\text { requirements on your products? }\end{array}$} & $\begin{array}{c}\text { Of a scale from 1 (totally unimportant) to } \mathbf{5} \text { (totally important), what is the importance that } \\
\text { the firm gives to the introduction of more sustainable technologies? }\end{array}$ \\
\cline { 2 - 7 } & 1 & 2 & 3 & 4 & 5 & Total Answers \\
\hline Excellent Compliance & $0.00 \%$ & $4.55 \%$ & $0.00 \%$ & $40.91 \%$ & $54.55 \%$ & 22 \\
\hline Moderate Compliance & $6.67 \%$ & $13.33 \%$ & $13.33 \%$ & $33.33 \%$ & $33.33 \%$ & 15 \\
\hline Low Compliance & $0.00 \%$ & $0.00 \%$ & $0.00 \%$ & $100.00 \%$ & $0.00 \%$ & 1 \\
\hline Null Compliance & $0.00 \%$ & $0.00 \%$ & $100.00 \%$ & $0.00 \%$ & $0.00 \%$ & 1 \\
\hline Total Answers & 1 & 3 & 3 & 15 & 17 & 39 \\
\hline
\end{tabular}

Secondly, firms were asked about the evolution of the use of water in the production process of the company in the last years. Compared to the importance given to sustainable development, results of the companies' actions are not as highly positive. While it is true that the categories "noticeably decreased" and "decreased" still compound more than $60 \%$, there is almost a $30 \%$ of the surveyed respondents that say the use of water has remained the same in their production process. Fortunately, only a small percentage of the firms increased it (Figure 6). 
How would you evaluate the evolution of the use of water in the production process of your company in recent years?

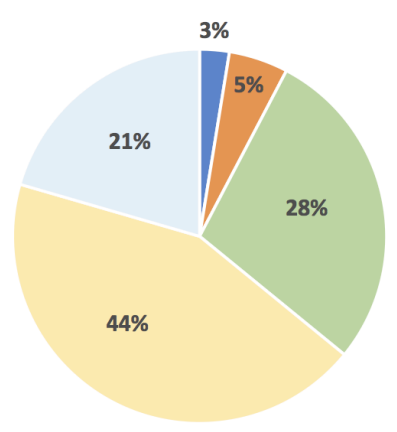

- Noticeably Increased $\quad$ Increased $\quad$ - Remains the Same $\quad$ Decreased Noticeably Decreased

Figure 6. Results obtained to the question: "How would you evaluate the evolution of the use of water in the production process of your company in recent years?

In order to analyze the correlation between the observed variables, obtained answers regarding the firms' degree of compliance in terms of technical certifications were compared with the answers related to the evolution of the use of water in the production process. Our presumption is that those firms that certify their products tend to ameliorate their production process, which includes an increase of awareness about the use of water and hence, a better use of it. In the obtained results, differences between groups of firms are more evident. Among those companies in the category "excellent compliance", more than 50\% chose the category "decreased", having the highest percentage. As it is observed, the rest of the answers were mainly distributed between the categories "noticeably decreased" and "remains the same", with around $22 \%$ each. Instead, firms under the category "moderate compliance" show a different tendency. The category with the most answers was "remains the same" ( $44 \%)$, followed by the category "decreased" (22\%), and the rest of the answers equally distributed in the remaining categories (Table 5). In addition, it is important to mention that not complying with NTMs does not necessarily mean that firms will increase the use of water in the production process, although it could be more likely. It was expected that low and null compliant firms would have more neutral answers. However, surprisingly the three of them have answered differently, which means there may not be a particular pattern when firms do not comply with these measures. Similar results are obtained when analyzing the degree of compliance in terms of packaging, which confirms these tendencies.

Last but not least, we analyze the correlation between the level of compliance with NTMs and the establishment of environmental performance goals. It is highlighted that $67 \%$ of the total surveyed firms confirmed to have established them, against $18 \%$ that have not, and $15 \%$ that preferred not to answer (Figure 7). However, when we divide these answers depending on the degree of compliance with technical certifications, we find that companies that comply with them establish environmental performance goals more than those who do not comply.

Table 5. Correlation between degree of compliance in terms of technical certifications and evolution of the use of water in the production process

\begin{tabular}{|c|c|c|c|c|c|c|}
\hline $\begin{array}{c}\text { What was your firm's level of } \\
\text { compliance in order to obtain } \\
\text { technical certifications required } \\
\text { by importing countries on your } \\
\text { products? }\end{array}$ & \multicolumn{5}{|c|}{ How would you evaluate the evolution of the use of water in the production process of } \\
\cline { 2 - 7 } & $\begin{array}{c}\text { Noticeably } \\
\text { Increased }\end{array}$ & Increased & $\begin{array}{c}\text { Remains the } \\
\text { Same }\end{array}$ & Decreased & $\begin{array}{c}\text { Noticeably } \\
\text { Decreased }\end{array}$ & Total Answers \\
\hline Excellent Compliance & $0.00 \%$ & $3.70 \%$ & $22.22 \%$ & $51.85 \%$ & $22.22 \%$ & 27 \\
\hline Moderate Compliance & $11.11 \%$ & $11.11 \%$ & $44.44 \%$ & $22.22 \%$ & $11.11 \%$ & 9 \\
\hline Low Compliance & $0.00 \%$ & $0.00 \%$ & $50.00 \%$ & $50.00 \%$ & $0.00 \%$ & 2 \\
\hline Null Compliance & $0.00 \%$ & $0.00 \%$ & $0.00 \%$ & $0.00 \%$ & $100.00 \%$ & 1 \\
\hline Total Answers & 1 & 2 & 11 & 17 & 8 & 39 \\
\hline
\end{tabular}


Has the company established environmental performance goals?

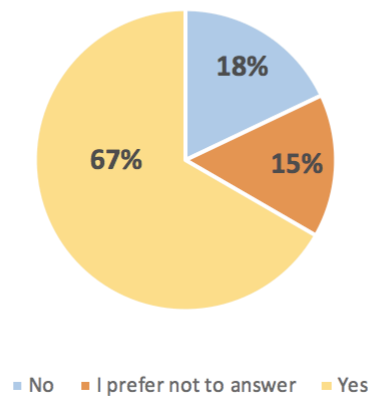

Figure 7. Results obtained to the question: "Has the company established environmental performance goals?"

Thus, we obtained that $86 \%$ of the firms under the category "excellent compliance" also chose the category "yes", against only around 5\% that said they have not established these types of goals. On the opposite side, two out of the three low and null compliant firms selected the category " $n o$ ", which gives more consistency of the tendency of these kinds of companies. Regarding the moderate compliant companies, we find once again that although there are more positive answers (43\%), the rest are equally distributed between the other two categories (Table 6).

Table 6. Correlation between degree of compliance with technical certifications and the establishment of environmental performance goals

\begin{tabular}{|c|c|c|c|c|}
\hline \multirow{2}{*}{$\begin{array}{c}\text { What was your firm's level of compliance in } \\
\text { order to obtain technical certifications } \\
\text { required by importing countries on your } \\
\text { products? }\end{array}$} & \multicolumn{3}{|c|}{ Has the company established environmental performance goals? } \\
\cline { 2 - 5 } & No & I prefer not to answer & Yes & Total Answers \\
\hline Excellent Compliance & $4.55 \%$ & $9.09 \%$ & $86.36 \%$ & 22 \\
\hline Moderate Compliance & $28.57 \%$ & $28.57 \%$ & $42.86 \%$ & 14 \\
\hline Low Compliance & $50.00 \%$ & $0.00 \%$ & $50.00 \%$ & 2 \\
\hline Null Compliance & $100.00 \%$ & $0.00 \%$ & $0.00 \%$ & 1 \\
\hline Total Answers & 7 & 6 & 26 & 39 \\
\hline
\end{tabular}

Thus, as we have observed in the results, there is a positive correlation between the degree of compliance in terms of Non-Tariff Measures and three factors: improvement of productive capacity and exports, perception of the application of these measures, and commitment with a sustainable development. In other words, companies who have complied with all or most packaging, technical certifications and maximum levels of contaminants/residues requirements tend to see a positive evolution of their exports and an improvement of their productive capacity. Additionally, they perceive the application of NTMs in a more positive way than those who comply less with them, and they show a better commitment to the environment and sustainability. It is important to highlight that we have had a very small quantity of firms that say to have had a low compliance or to have not complied at all with these measures. Hence, some of the indicators show no clear pattern of how these companies would behave, which could mean either that these kinds of firms may perform differently depending on each case, or that the surveyed firms are simply outsiders.

\section{Conclusion}

As globalization continues to progress and foreign trade is increasingly encouraged by the decrease of transportation costs, tariffs and other traditional barriers, countries have started to apply Non-Tariff Measures. These standards have become a primary concern in global trade, as they now constitute the most important barriers to business between countries. Developed countries, in particular the EU, have 
extensively applied sanitary and phytosanitary measures in the form of technical certifications, maximum limits of contaminants, packaging requirements, laboratory inspections, and others.

While many experts claim that they negatively affect trade in developing countries, these impacts may vary depending on the firms' degree of compliance with these measures. The aim of this paper was to show that SPS can have positive impacts in the long term. Through a qualitative research, we did a case analysis of the application of sanitary and phytosanitary measures in the tea, coffee and yerba mate industry in Latin America.

In our research, we highlight three main results. First, those companies that complied with all of SPS (or most of them) have a more positive view regarding their application and their effects in the long-term than those firms that comply less with them or do not comply at all. Second, there is a tendency in those firms who comply more to increase their productive capacity and their exports, compared to those that comply less or do not comply. Third, firms who tend to comply with SPS show more commitment to an environmental and sustainable development. According to our results, the more they comply, the more importance they give to sustainable technologies, the more they tended to reduce the use of water in the production process, and the more they have established environmental performance goals in the last years.

In conclusion, the application of Non-Tariff Measures can have positive effects in international business. Although it may be true that firms face new unprecedented costs, when they comply with these standards, they introduce new sustainable technologies, include sustainable plans for the company and improve the quality of their products and production process, which would eventually help them to become more competitive, increase their production capacity and their exports, and become more profitable.

\section{References}

Brenes, Guillermo Canet and Viquez, Carlos Soto. 2016. La situación y tendencias de la producción de café en América Latina y el Caribe. Guadalajara, Mexico: Centro de Investigación y Asistencia en Tecnología y Diseño del Estado de Jalisco A.C. Instituto Interamericano de Cooperación para la Agricultura.

FAOSTAT. 2018. Statistic data available at: http://www.fao.org/faostat/en/?\#data/QC

Galperin, Carlos. 2013. El impacto de las medidas sanitarias y fitosanitarias y de los reglamentos técnicos sobre las exportaciones agrícolas: una revisión de los estudios cuantitativos. Buenos Aires, Argentina: Notes of CEI N. 32. National Directorate of the Center for International Economics.

Honduran Coffee Institute (IHCAFE). 2017. Statistical report 2016-2017. Harvest report 2016-2018.

International Coffee Organization. 2018. Evolución de las Corrientes del comercio de café. Mecico City, Mexico: International Coffee Council. $121^{\text {st }}$ period of periods.

Kim, Maria Esther. 2018. La aplicación de medidas ambientales y sanitarias de la Unión Europea en el comercio de infusiones latinoamericano (1995-2015). Buenos Aires, Argentina: University of Buenos Aires. 